\title{
Use of polymer-supported amines in the catalytic nitro-aldol reaction of nitroalkanes with aldehydes
}

\author{
Francisco Palacios,* Jesús M. de los Santos, and Domitila Aparicio \\ Departamento de Química Orgánica I. Facultad de Farmacia. Universidad del País Vasco. \\ Apartado 450. 01080 Vitoria-Gasteiz. Spain \\ E-mail:qoppagaf@,vf.ehu.es
}

\section{Dedicated to Professors José Elguero and Pedro Molina on the occasion of their $70^{\text {th }}$ and $60^{\text {th }}$ anniversaries, respectively}

(received 18 Mar 05; accepted 21 Jun 05; published on the web 28 Jun 05)

\begin{abstract}
An efficient catalytic synthesis of 2-nitroalcohols has been achieved through a catalytic nitroaldol (Henry) reaction promoted by polymer-supported amines. These achiral and chiral polymer-bound amines show general utility in their reactions with a variety of aromatic and functionalized aldehyde acceptors. Moreover, the catalyst can be reused without loss of activity.
\end{abstract}

Keywords: Achiral and chiral polymer-bound amines, catalytic nitro-aldol, 2-nitroalcohols, polymer-supported catalysts

\section{Introduction}

The capability for high-throughput screening of potential drug substances is placing everincreasing demands on the methods for the fast and efficient generation of new pharmacological targets. In general, chemical libraries or arrays containing a large number of compounds may be prepared either on polymer supports or in solution. ${ }^{\text {la }}$ While most of the published work on small molecule library synthesis has been performed using solid supports, solution-phase strategies have been applied successfully by a number of researchers. The advantages of polymersupported reactions (e.g., that the reaction is accelerated by using an excess of the soluble reaction partner without the need for additional purification steps) and the benefits of solutionphase chemistry (e.g., the ease of monitoring the process of the reactions by applying TLC, LCMS or NMR techniques) can be combined by using polymer-supported reagents. Polymer-bound reagents have been utilized widely for many chemical transformations in organic chemistry. ${ }^{1 b}$ Two of the most significant advantages of these reagents over their soluble counterparts are their ability to drive the reaction to completion by using an excess, and the ease of their separation 
from the desired product by filtration. Furthermore, there is a constant need for new methodologies which can be applied to the preparation of heterocycles and small organic molecules. ${ }^{2,3}$ For this reason the development of new polymer-supported reagents has attracted growing interest in recent years. Recent work by our group has focused on the development of new bases ${ }^{4,5}$ and of new polymer-supported catalysts for the preparation of enantiomerically enriched $2 \mathrm{H}$-azirines derived from phosphine oxides ${ }^{5 \mathrm{a}}$ and phosphonates. ${ }^{5 \mathrm{~b}}$ We now report a further example using achiral- and chiral- polymer-supported amines for the construction of carbon-carbon bonds by nitroalkanes through the nitro-aldol (Henry) reaction.

The Henry- or nitro-aldol- reaction is a classical yet powerful carbon-carbon bond-forming process in organic chemistry, ${ }^{6}$ by which 2-nitroalcohols are formed by treating primary or secondary nitroalkanes with a base and carbonyl compounds, providing efficient access to valuable synthetic building blocks such as $\beta$-aminoalcohols and $\alpha$-hydroxycarboxylic acids. ${ }^{7}$ Nitroalcohols are useful intermediates in the elaboration of pharmacologically important derivatives, including hepatotoxin, 7-epicylindrospermopsin, ${ }^{8 \mathrm{a}}$ Taxotere $^{\circledR 8}{ }^{8 b, c}$ side-chain and (-)bestatin, ${ }^{8 b, c}$ the $\beta$-receptor agonists $(-)$-denopamine ${ }^{8 \mathrm{~d}}$ and $(-)$-arbutamine, ${ }^{8 \mathrm{~d}, \mathrm{e}}$ the $\beta$-blocker (S)propanolol, $^{8 \mathrm{f}}$ and antibiotics such as chloroamphenicol, ephedrine, nor-ephedrine and anthracycline. ${ }^{8 \mathrm{~g}, \mathrm{~h}}$ The most commonly applied protocols for performing the above reaction require the use of basic catalysts under homogeneous or heterogeneous conditions. ${ }^{9}$

Bases such as phosphorus ylides, ${ }^{4}$ cyclic guanidines, ${ }^{10 \mathrm{a}}$ and ammonium salts, ${ }^{10 \mathrm{~b}}$ have been applied in the nitro-aldol reaction ${ }^{10}$ and an asymmetric version of this reaction which uses an optically active metal catalyst has recently been developed. ${ }^{11,12}$ However, to our knowledge, there are no literature reports on the nitro-aldol reaction of nitroalkanes with aldehydes promoted by achiral or chiral polymer-supported amines as catalysts. Herein we explore the applicability of these resins in catalytic asymmetric nitro-aldol reactions.

\section{Results and Discussion}

To evaluate the catalytic efficiency of the polymer-supported amines 3 , the reaction of $\mathrm{p}$ nitrobenzaldehyde 1a with nitroethane, 2a, was examined. Thus, treatment of 1a with nitroethane 2a in the presence of commercially available polymer-supported amine derived from diethylamine, 3a, $(50 \mathrm{~mol}$. \%) at room temperature for $3 \mathrm{~h}$, resulted in clean formation of the corresponding nitroalcohol 4a as a diastereomeric mixture [( \pm -syn/anti, 1:1] in $84 \%$ yield (Scheme 1, Table 1, entry 1). Further, the catalyst-loading can be reduced to $10 \mathrm{~mol}$. \% without significant loss of reactivity, to afford a mixture of $( \pm)$-syn-and ( \pm )-anti-nitroalcohols with low diastereoselectivity (Table 1, entry 2). 


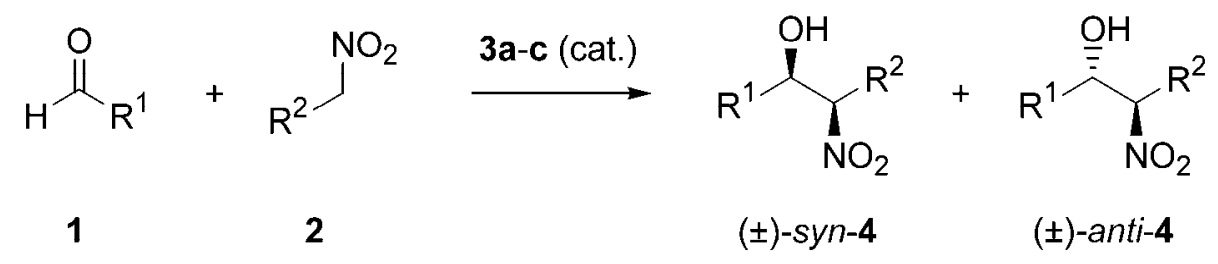

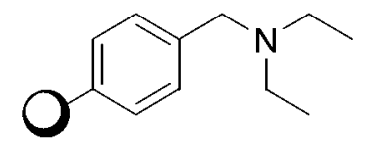

$3 a$

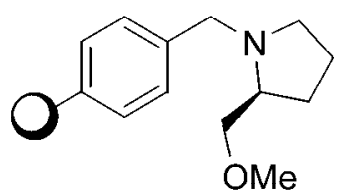

$3 b$

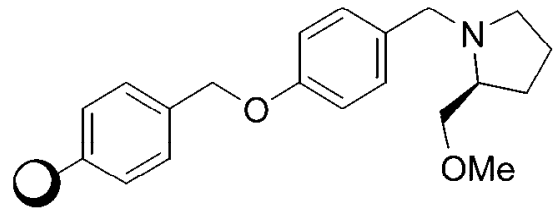

$3 c$

\section{Scheme 1}

Table 1. Nitroaldol reaction of aldehydes with nitroalkanes catalyzed by polymer-supported amines 3a-c

\begin{tabular}{|c|c|c|c|c|c|c|}
\hline Entry & Product & $\mathrm{R}^{1}$ & $\mathrm{R}^{2}$ & $\begin{array}{l}\text { Catalyst } \\
(\% \text { mol. })\end{array}$ & $\tau(\%)^{\mathrm{a}}$ & $\begin{array}{l}(\%) \text { Yield }^{b} \\
(\text { syn / anti) }\end{array}$ \\
\hline 1 & $4 a$ & $\mathrm{p}-\mathrm{NO}_{2}-\mathrm{C}_{6} \mathrm{H}_{4}-$ & $\mathrm{Me}$ & За (50) & $>99$ & $84(50: 50)$ \\
\hline 2 & $4 a$ & $\mathrm{p}-\mathrm{NO}_{2}-\mathrm{C}_{6} \mathrm{H}_{4}-$ & $\mathrm{Me}$ & 3a (10) & 97 & $95(50: 50)$ \\
\hline 3 & $4 a$ & $\mathrm{p}-\mathrm{NO}_{2}-\mathrm{C}_{6} \mathrm{H}_{4}-$ & $\mathrm{Me}$ & $3 \mathbf{b}(15)$ & 95 & $66(50: 50)$ \\
\hline 4 & $4 a$ & $\mathrm{p}-\mathrm{NO}_{2}-\mathrm{C}_{6} \mathrm{H}_{4}-$ & $\mathrm{Me}$ & $3 c(20)$ & $>99$ & $81(56: 44)$ \\
\hline 5 & $4 b$ & $\mathrm{p}-\mathrm{NO}_{2}-\mathrm{C}_{6} \mathrm{H}_{4}-$ & $\mathrm{H}$ & $3 c(10)$ & 92 & 60 \\
\hline 6 & $4 c$ & $\mathrm{p}-\mathrm{Me}-\mathrm{C}_{6} \mathrm{H}_{4}-$ & $\mathrm{Me}$ & 3c $(20)$ & 83 & $26(64: 36)$ \\
\hline 7 & 4d & $\mathrm{p}-\mathrm{Cl}-\mathrm{C}_{6} \mathrm{H}_{4}-$ & $\mathrm{Me}$ & 3c (20) & 72 & $49(57: 43)$ \\
\hline 8 & $4 e$ & p-F-C ${ }_{6} \mathrm{H}_{4}-$ & $\mathrm{Me}$ & 3c (20) & n.d. & 38 (n.d.) \\
\hline 9 & $\mathbf{4 f}$ & $\mathrm{CO}_{2} \mathrm{Et}$ & $\mathrm{Me}$ & 3c $(20)$ & $>99$ & 87 (n.d.) \\
\hline 10 & $4 f$ & $\mathrm{CO}_{2} \mathrm{Et}$ & $\mathrm{Me}$ & $3 c(20)^{d}$ & $>99$ & 80 (n.d.) \\
\hline 11 & $4 g$ & $\mathrm{CO}_{2} \mathrm{Et}$ & $\mathrm{H}$ & 3a (20) & $>99$ & 69 \\
\hline
\end{tabular}

${ }^{a}$ The conversion $(\tau)$ was calculated by ${ }^{1} \mathrm{H}$ - NMR analysis of the crude reaction mixture. ${ }^{b}$ Values are isolated yields after chromatographic purification. ${ }^{c}$ The syn / anti ratio was determined by ${ }^{1} \mathrm{H}$ - NMR analysis of the crude reaction mixture. ${ }^{d}$ Recovered catalyst used once in Entry 9.

The spectroscopic data were in agreement with the assigned structure of compound $\mathbf{4 a} .{ }^{13}$ The ${ }^{1} \mathrm{H}$ - NMR spectrum showed an absorption at $\delta_{\mathrm{H}} 5.21 \mathrm{ppm}$ as a doublet with coupling constant ${ }^{3} \mathrm{~J}_{\mathrm{HH}}=8.5 \mathrm{~Hz}$ for the methylene proton directly bonded to the hydroxyl group of compound $( \pm)$ syn-4a, while the methylene proton directly bonded to the hydroxyl group of diastereoisomer $( \pm)$-anti-4a resonates at $\delta_{\mathrm{H}} 5.58 \mathrm{ppm}\left({ }^{3} \mathrm{~J}_{\mathrm{HH}}=3.3 \mathrm{~Hz}\right)$. 
In order to extend this process to the asymmetric synthesis of nitroalcohols 4 , the chiral polymer-supported amine $3 \mathbf{b}^{5 \mathrm{a}}$ derived from Merrifield resin and $(S)-(+)-2-$ (methoxymethyl)pyrrolidine was used. This chiral $\mathbf{3 b}$ was used as the chiral base in the nitroaldol reaction of aldehydes with nitroalkanes, in a similar way to that reported before for the achiral resin amine 3a, to give the nitroalcohol 4a in moderate yield (no appreciable diastereoselectivity was observed) (Scheme 1, Table 1, entry 3). The enantiopurity of nitroalcohol 4a was examined by HPLC analysis using a chiral column (DAICEL Chiralcel ODH) with hexane/2-propanol as solvent, but showed no enantioselectivity.

Finally, to improve both the diastereo- and enantio-selectivities, the chiral supported base 3c derived from $(S)-(+)-2-($ methoxymethyl)pyrrolidine was synthesized. The preparation of this polystyrene chiral resin 3c can be achieved by attachment of the chiral secondary amine to the solid support using Wang resin. Wang resin was reacted with $(S)-(+)-2$ (methoxymethyl)pyrrolidine at $65^{\circ} \mathrm{C}$ in DMF to afford the new chiral resin $3 c .{ }^{14}$ This chiral polymer-supported amine 3c was then used as chiral base in the nitro-aldol reaction using aromatic- and functionalized aldehydes. Thus, treatment of aromatic (Scheme 1, Table 1, entries 4-8) and functionalized aldehydes (entries 9-10) with nitromethane or nitroethane in the presence of polymer-supported chiral amine 3c (10-20 mol. \%), afforded the corresponding nitroalcohols 4 with low diastereoselectivities and no enantiomeric excess.

Combination of polymer-supported reactions and solution-phase chemistry allows the preparation of 2-nitroalcohols 4 after filtration of the corresponding polymer-supported amines 3 . These polymer-supported amines $\mathbf{3}$, after activation, were efficiently recycled for further cycles without loss of activity (Table 1, entry 10).

The high synthetic potential of the Henry reaction has been demonstrated previously for $\beta$ nitroalcohols ${ }^{15}$ and for $\beta$-nitro- $\alpha$-amino acid derivatives, ${ }^{16}$ as well as for the easy conversion of the $\beta$-nitro- $\alpha$-hydroxy acid derivatives into a variety of important functionalities - for example, $\beta$-amino- $\alpha$-hydroxy esters. ${ }^{17}$ During the last several years, enantioselective synthesis of $\beta$-amino$\alpha$-hydroxy acids has attracted much attention not only because of the synthetic interest to put the right functional moieties in the right positions in a stereospecific manner but also because of their presence in various medicinally important molecules. ${ }^{18}$ Paclitaxel, one of the most promising anticancer agents so far discovered, has 2-( $N$-benzoylamino)-2-hydroxy-3phenylpropionic acid as a side chain for the essential structural element for the activity. ${ }^{19 a}$ Another member of this class of compounds bearing 3-amino-2-hydroxy-5-methyl hexanoate as a key component is amastatin, with immunoregulatory, antitumor, and antibacterial activity. ${ }^{19 \mathrm{~b}}$ The $\beta$-amino- $\alpha$-hydroxy acid is also found in renin inhibitor for antihypertensive agent, as the transition state mimic including KRI $1314,{ }^{19 \mathrm{c}}$ bestatin, ${ }^{19 \mathrm{~d}}$ - a dipeptide with antitumor and antibacterial activities — and microginin ${ }^{19} \mathrm{e}$ - a linear pentapeptide natural product which showed angiotensin-converting enzyme inhibitory activity.

A straightforward synthetic route to $\beta$-amino- $\alpha$-hydroxy acid derivatives can be designed by hydrogenolysis of starting $\beta$-nitro- $\alpha$-hydroxy esters as shown in Scheme 2 . Thus, for the $\beta$-nitro- 
$\alpha$-hydroxy ester $4 \mathbf{f}$ (catalyst $3 \mathbf{c}$ used) the reduction of the nitro group was performed using Raney-Ni to give the amino ester 5 in $68 \%$ yield (Scheme 2).<smiles>CCOC(=O)[C@H](O)[C@H](C)[N+](=O)[O-]</smiles>

$4 f$

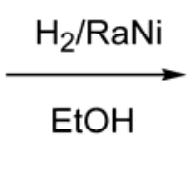

(1)

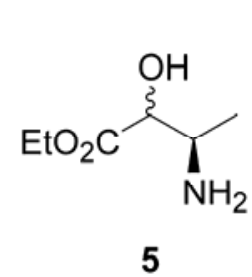

\section{Scheme 2}

In summary, we have demonstrated the ability of achiral and chiral polymer-supported amines 3a-c as highly active promoters of the addition of nitroalkanes to aldehydes. Nitroalcohols are valuable synthetic building blocks in the elaboration of pharmacologically important derivatives. ${ }^{7,8}$ Furthermore, it was shown that the $\beta$-nitro- $\alpha$-hydroxy esters can be converted into synthetically valuable $\beta$-amino- $\alpha$-hydroxy esters. This methodology combine the advantages of polymer-supported reactions and the benefits of solution-phase chemistry, allowing automated implementation of these processes in a way similar to that reported for the synthesis of other small molecule libraries.

\section{Experimental Section}

General Procedures. Solvents for extraction and chromatography were of technical grade. All solvents used in reactions were freshly distilled. All other reagents were recrystallized or distilled as necessary. All reactions were performed under an atmosphere of dry nitrogen. Analytical TLC was performed with silica-gel $60 \mathrm{~F}_{254}$ plates. Spot visualization was accomplished by using UV light or $\mathrm{KMnO}_{4}$ solution. Flash chromatography was carried out using silica gel 60 (230-400 mesh). Melting points were determined with an Electrothermal IA9100 digital apparatus and are uncorrected. ${ }^{1} \mathrm{H}-(400 \mathrm{MHz})$ and ${ }^{13} \mathrm{C}-(100 \mathrm{MHz})$ spectra were recorded on a Bruker Avance 400 $\mathrm{MHz}$ spectrometer, with tetramethylsilane (TMS) $(0.00 \mathrm{ppm})$ or chloroform $(7.24 \mathrm{ppm})$ as internal reference in $\mathrm{CDCl}_{3}$ solutions for ${ }^{1} \mathrm{H}$ - NMR spectra, or chloroform (77.0 ppm) as internal reference in $\mathrm{CDCl}_{3}$ solutions for ${ }^{13} \mathrm{C}$ - NMR spectra. Chemical shifts $(\delta)$ are given in ppm; multiplicities are indicated by s (singlet), brs (broad singlet), $d$ (doublet), dd (double-doublet), $t$ (triplet), q (quadruplet) or $\mathrm{m}$ (multiplet); coupling constants ( $\mathrm{J}$ ) are in Hz. Low-resolution mass spectra (MS) were obtained on a Hewlett Packard 5971 MSD Series spectrometer at 50-70 eV by electron impact (EI), or a Hewlett Packard 1100 MSD Series spectrometer by chemical ionization (CI). Data are reported in the form $\mathrm{m} / \mathrm{z}$ (intensity relative to base peak $=100$ ). Infrared spectra (IR) (in $\mathrm{cm}^{-1}$ ) were taken on a Nicolet FTIR Magna 550 spectrometer, and were obtained for solids in $\mathrm{KBr}$ or for neat oils ( $\mathrm{NaCl}$ plates). Elemental analyses were performed in a Perkin 
Elmer Model 240 instrument. (S)-(+)-2-(methoxymethyl)pyrrolidinomethyl polystyrene resin $3 \mathbf{b}^{5 \mathrm{a}}$ was synthesized according to literature procedures. RT denotes room temperature

Synthesis of (S)-(+)-2-(methoxymethyl)pyrrolidine Wang resin (3c). A suspension of Wang chlorinated resin (4 mmol, 0.5-1.0 $\mathrm{mmol}$ of $\mathrm{Cl} / \mathrm{g}$ resin, $5.34 \mathrm{~g}$ ) in DMF $(40 \mathrm{ml})$ was treated with $(S)-(+)-2-($ methoxymethyl)pyrrolidine $(16 \mathrm{mmol}, 2 \mathrm{ml})$. The resulting mixture was shaken at $65{ }^{\circ} \mathrm{C}$ for $18 \mathrm{~h}$ under $\mathrm{N}_{2}$ and then allowed to stand at RT for $24 \mathrm{~h}$. After this time, the resin was filtered and washed successively with $\mathrm{MeOH}, \mathrm{DMF}, \mathrm{MeOH}, \mathrm{CH}_{2} \mathrm{Cl}_{2}, \mathrm{MeOH}, \mathrm{CH}_{2} \mathrm{Cl}_{2}, \mathrm{MeOH}$, AcOEt, and pentane. The resulting polymer-supported amine was dried at $20{ }^{\circ} \mathrm{C}$ under vacuum for $12 \mathrm{~h}$ and stored in tightly sealed bottles. Data for 3c: IR (KBr) 2806 (OMe st.), 1096 (C-O-C st.) $\mathrm{cm}^{-1}$; Anal. Found: C, 85.42; H, 8.07; N, 1.54 .

\section{General procedure for the synthesis of 2-nitroalcohols 4}

To a suspension of resin-supported amine 3a-c (ca. $0.2 \mathrm{mmol}, 0.2$ equiv.) in nitroalkane (5.0 ml) was added the corresponding aldehyde 1 ( $1 \mathrm{mmol}, 1$ equiv.). The mixture was shaken at RT or $60{ }^{\circ} \mathrm{C}$ under $\mathrm{N}_{2}$ atmosphere, after which the resin was filtered off, and washed with $\mathrm{CH}_{2} \mathrm{Cl}_{2}$ $(5 \mathrm{ml}), \mathrm{Et}_{2} \mathrm{O}(5 \mathrm{ml}), \mathrm{CH}_{2} \mathrm{Cl}_{2}(5 \mathrm{ml})$ and $\mathrm{Et}_{2} \mathrm{O}(5 \mathrm{ml})$. The filtrate was evaporated under vacuum and the crude product purified by flash-chromatography (silica gel, $\mathrm{Et}_{2} \mathrm{O}$-hexanes, 1:20) to yield compounds 4. Resin-supported amines 3a-c were recovered by washing successively with $\mathrm{MeOH}(3 \mathrm{x}), \mathrm{CH}_{2} \mathrm{Cl}_{2}$ (3x), TEA (3x), TEA/CH $\mathrm{Cl}_{2}$ (1:1) (3x), $\mathrm{CH}_{2} \mathrm{Cl}_{2}$ (3x), $\mathrm{MeOH}$ (3x). The resulting polymer-supported amine $3 a-c$ was dried at $20^{\circ} \mathrm{C}$ under vacuum for $12 \mathrm{~h}$ and stored in tightly sealed bottles.

( \pm -anti- and syn-2-Nitro-1-p-nitrophenylpropan-1-ol (4a). ${ }^{13}$ (A) Prepared as described in the general procedure, $190 \mathrm{mg}(84 \%)$ was obtained as a white solid from p-nitrobenzaldehyde 1a, nitroethane 2a and resin-supported amine 3a ( 0.5 equiv.) at RT for $3 \mathrm{~h}$. (B) By the general procedure, $215 \mathrm{mg}(95 \%)$ was obtained as a white solid from p-nitrobenzaldehyde 1a, nitroethane 2a and resin-supported amine 3a (0.1 equiv.) at RT for $17 \mathrm{~h}$. (C) By the general procedure, (149 mg, 66\%) was obtained as a white solid from p-nitrobenzaldehyde 1a, nitroethane 2a and resin-supported amine $3 \mathbf{b}$ ( 0.15 equiv.) at RT for $23 \mathrm{~h}$. (D) As described in the general procedure, $183 \mathrm{mg}(81 \%)$ was obtained as a white solid from p-nitrobenzaldehyde 1a, nitroethane 2a and resin-supported amine 3c (0.2 equiv.) at RT for $17 \mathrm{~h}$. Data for 4a: mp 91$93{ }^{\circ} \mathrm{C} ;{ }^{1} \mathrm{H}-\mathrm{NMR}\left(\mathrm{CDCl}_{3}\right) \delta 8.28\left(\mathrm{~d},{ }^{3} \mathrm{~J}_{\mathrm{HH}}=8.8 \mathrm{~Hz}, 2 \mathrm{H}\right), 8.27\left(\mathrm{~d},{ }^{3} \mathrm{~J}_{\mathrm{HH}}=8.8 \mathrm{~Hz}, 2 \mathrm{H}\right), 7.62\left(\mathrm{~d},{ }^{3} \mathrm{~J}_{\mathrm{HH}}\right.$ $=8.8 \mathrm{~Hz}, 2 \mathrm{H}), 7.62\left(\mathrm{~d},{ }^{3} \mathrm{~J}_{\mathrm{HH}}=8.8 \mathrm{~Hz}, 2 \mathrm{H}\right), 5.58\left(\mathrm{~d},{ }^{3} \mathrm{~J}_{\mathrm{HH}}=3.3 \mathrm{~Hz}, 1 \mathrm{H}\right), 5.21\left(\mathrm{~d},{ }^{3} \mathrm{~J}_{\mathrm{HH}}=8.5 \mathrm{~Hz}\right.$, $1 \mathrm{H}), 4.82-4.76(\mathrm{~m}, 1 \mathrm{H}), 4.76-4.70(\mathrm{~m}, 1 \mathrm{H}), 2.98$ (brs, $1 \mathrm{H}), 2.98$ (brs, $1 \mathrm{H}), 1.51\left(\mathrm{~d},{ }^{3} \mathrm{~J}_{\mathrm{HH}}=6.7 \mathrm{~Hz}\right.$, $3 \mathrm{H}), 1.40\left(\mathrm{~d},{ }^{3} \mathrm{~J}_{\mathrm{HH}}=6.7 \mathrm{~Hz}, 3 \mathrm{H}\right) \mathrm{ppm} ;{ }^{13} \mathrm{C}-\mathrm{NMR}\left(\mathrm{CDCl}_{3}\right) \delta 148.3,147.9,145.5,145.3,127.9$, 127.0, 124.1, 124.0, 87.8, 86.8, 75.1, 72.9, 16.311 .9 ppm; IR (KBr) 3562, 3523, 1561, 1523, $1346 \mathrm{~cm}^{-1}$; MS (EI) m/z 151 (100), 150 (90), 77 (70). Anal. Calcd. for $\mathrm{C}_{9} \mathrm{H}_{10} \mathrm{~N}_{2} \mathrm{O}_{5}$ : C, 47.79; H, 4.46; N, 12.39. Found: C, 47.84; H, 4.40; N, 12.09\%.

( \pm )-2-Nitro-1-p-nitrophenylethan-1-ol (4b). ${ }^{20}$ By the general procedure, $127 \mathrm{mg}(60 \%)$ was obtained as a white solid from p-nitrobenzaldehyde 1a, nitromethane $\mathbf{2 b}$ and resin-supported 
amine 3c $(0.1$ equiv. $)$ at $60{ }^{\circ} \mathrm{C}$ for $48 \mathrm{~h}$. Data for $4 \mathbf{b}: \mathrm{mp} 85-86{ }^{\circ} \mathrm{C} ;{ }^{1} \mathrm{H}-\mathrm{NMR}\left(\mathrm{CDCl}_{3}\right) \delta 8.22(\mathrm{~d}$, $\left.{ }^{3} \mathrm{~J}_{\mathrm{HH}}=8.8 \mathrm{~Hz}, 2 \mathrm{H},\right), 7.63\left(\mathrm{~d},{ }^{3} \mathrm{~J}_{\mathrm{HH}}=8.8 \mathrm{~Hz}, 2 \mathrm{H}\right), 5.64-5.60(\mathrm{~m}, 1 \mathrm{H}), 4.65-4.58(\mathrm{~m}, 2 \mathrm{H}), 3.70$ (brs, $1 \mathrm{H}) \mathrm{ppm} ;{ }^{13} \mathrm{C}-\mathrm{NMR}\left(\mathrm{CDCl}_{3}\right) \delta 148.2,145.0,126.9,124.2,80.6,69.9 \mathrm{ppm}$; IR (KBr) 3443, 1540, 1513, $1341 \mathrm{~cm}^{-1}$; MS (EI) m/z 151 (100), 150 (87), 77 (66). Anal. Calcd. for $\mathrm{C}_{8} \mathrm{H}_{8} \mathrm{~N}_{2} \mathrm{O}_{5}$ : C, 45.29; H, 3.80; N, 13.20. Found: C, 44.90; H, 3.82; N, 13.11\%.

( \pm )-anti- and syn-2-Nitro-1-p-tolylpropan-1-ol (4c). ${ }^{10 \mathrm{~b}}$ By the general procedure, $51 \mathrm{mg}(26 \%)$ was obtained as a pale yellow oil from p-tolualdehyde $\mathbf{1 b}$, nitroethane $\mathbf{2 a}$ and resin-supported amine 3c (0.2 equiv.) at reflux for 48h. Data for 4c: ${ }^{1} \mathrm{H}-\mathrm{NMR}\left(\mathrm{CDCl}_{3}\right) \delta 7.28-7.20(\mathrm{~m}, 8 \mathrm{H})$, 5.34-5.32 (m, 1H), $4.99\left(\mathrm{~d},{ }^{3} \mathrm{~J}_{\mathrm{HH}}=9.1 \mathrm{~Hz}, 1 \mathrm{H}\right), 4.81-4.73(\mathrm{~m}, 1 \mathrm{H}), 4.72-4.66(\mathrm{~m}, 1 \mathrm{H}), 2.82$ (brs, $1 \mathrm{H}), 2.71(\mathrm{brs}, 1 \mathrm{H}), 2.38(\mathrm{~s}, 3 \mathrm{H}), 2.37(\mathrm{~s}, 3 \mathrm{H}), 1.51\left(\mathrm{~d},{ }^{3} \mathrm{~J}_{\mathrm{HH}}=6.8 \mathrm{~Hz}, 3 \mathrm{H}\right), 1.31\left(\mathrm{~d},{ }^{3} \mathrm{~J}_{\mathrm{HH}}=6.8\right.$ $\mathrm{Hz}, 3 \mathrm{H}) \mathrm{ppm} ;{ }^{13} \mathrm{C}-\mathrm{NMR}\left(\mathrm{CDCl}_{3}\right) \delta 139.1,138.4,135.5,135.4,129.7,129.4,126.9,125.9,88.5$, 87.5, 76.2, 74.0, 21.2, 21.2, 16.5, 12.3 ppm; IR ( NaCl) 3463, 2919, 1686, 1554, 1461, 1381, $1355 \mathrm{~cm}^{-1}$; MS (EI) m/z 120 (88), 119 (100), 91 (96), 65 (25). Anal. Calcd. for $\mathrm{C}_{10} \mathrm{H}_{13} \mathrm{NO}_{3}: \mathrm{C}$, 61.53 ; H, 6.71; N, 7.18. Found: C, 61.49; H, 6.59; N, 7.14\%.

( \pm )-anti- and syn-1-p-Chlorophenyl-2-nitropropan-1-ol (4d). ${ }^{21}$ By the general procedure, 106 $\mathrm{mg}(49 \%)$ was obtained as a pale yellow oil from p-chlorobenzaldehyde 1c, nitroethane 2a and resin-supported amine $3 \mathbf{c}(0.2$ equiv. $)$ at $\mathrm{RT}$ for $72 \mathrm{~h}$. Data for $\mathbf{4 d}$ : ${ }^{1} \mathrm{H}-\mathrm{NMR}\left(\mathrm{CDCl}_{3}\right) \delta$ 7.36-7.24 $(\mathrm{m}, 8 \mathrm{H}), 5.33\left(\mathrm{t},{ }^{3} \mathrm{~J}_{\mathrm{HH}}=3.6 \mathrm{~Hz}, 1 \mathrm{H}\right), 4.97\left(\mathrm{dd},{ }^{3} \mathrm{~J}_{\mathrm{HH}}=3.9 \mathrm{~Hz},{ }^{3} \mathrm{~J}_{\mathrm{HH}}=8.9 \mathrm{~Hz}, 1 \mathrm{H}\right), 4.72-4.67(\mathrm{~m}$, $1 \mathrm{H}), 4.66-4.61(\mathrm{~m}, 1 \mathrm{H}), 2.95\left(\mathrm{~d},{ }^{3} \mathrm{~J}_{\mathrm{HH}}=3.8 \mathrm{~Hz}, 1 \mathrm{H}\right), 2.91\left(\mathrm{~d},{ }^{3} \mathrm{~J}_{\mathrm{HH}}=4.1 \mathrm{~Hz}, 1 \mathrm{H}\right), 1.44\left(\mathrm{~d},{ }^{3} \mathrm{~J}_{\mathrm{HH}}=\right.$ $6.8 \mathrm{~Hz}, 3 \mathrm{H}), 1.28\left(\mathrm{~d},{ }^{3} \mathrm{~J}_{\mathrm{HH}}=6.8 \mathrm{~Hz}, 3 \mathrm{H}\right) \mathrm{ppm} ;{ }^{13} \mathrm{C}-\mathrm{NMR}\left(\mathrm{CDCl}_{3}\right) \delta 136.9,136.7,135.0,134.3$, 129.1, 128.9, 128.2, 127.3, 88.1, 87.2, 75.4, 73.2, 16.3, 11.9 ppm; IR (NaCl) 3516, 1554, 1387, $1096 \mathrm{~cm}^{-1}$; MS (EI) m/z 140 (73), 139 (100), 111 (46), 75 (31). Anal. Calcd. for $\mathrm{C}_{9} \mathrm{H}_{10} \mathrm{ClNO}_{3}: \mathrm{C}$, 50.13 ; H, 4.67; N, 6.50. Found: C, 50.01; H, 4.50; N, 6.39\%.

(士)-anti- and syn-1-p-Fluorophenyl-2-nitropropan-1-ol (4e). As described in the general procedure, $4 \mathbf{e}(76 \mathrm{mg}, 38 \%)$ was obtained as a pale yellow oil from p-fluorobenzaldehyde 1d, nitroethane 2a and resin-supported amine $3 \mathbf{c}\left(0.2\right.$ equiv.) at reflux for $96 \mathrm{~h}$. Data for 4e: ${ }^{1} \mathrm{H}-\mathrm{NMR}$ $\left(\mathrm{CDCl}_{3}\right) \delta 7.40-7.08(\mathrm{~m}, 8 \mathrm{H}), 5.32\left(\mathrm{~d},{ }^{3} \mathrm{~J}_{\mathrm{HH}}=3.5 \mathrm{~Hz}, 1 \mathrm{H}\right), 4.98\left(\mathrm{~d},{ }^{3} \mathrm{~J}_{\mathrm{HH}}=8.8 \mathrm{~Hz}, 1 \mathrm{H}\right), 4.73-4.66$ $(\mathrm{m}, 1 \mathrm{H}), 4.65-4.60(\mathrm{~m}, 1 \mathrm{H}), 2.80\left(\mathrm{~d},{ }^{3} \mathrm{~J}_{\mathrm{HH}}=3.5 \mathrm{~Hz}, 1 \mathrm{H}\right), 2.69\left(\mathrm{~d},{ }^{3} \mathrm{~J}_{\mathrm{HH}}=4.1 \mathrm{~Hz}, 1 \mathrm{H}\right), 1.52(\mathrm{~d}$, $\left.{ }^{3} \mathrm{~J}_{\mathrm{HH}}=6.8 \mathrm{~Hz}, 3 \mathrm{H}\right), 1.34\left(\mathrm{~d},{ }^{3} \mathrm{~J}_{\mathrm{HH}}=7.0 \mathrm{~Hz}, 3 \mathrm{H}\right) \mathrm{ppm} ;{ }^{13} \mathrm{C}-\mathrm{NMR}\left(\mathrm{CDCl}_{3}\right) \delta 162.9\left(\mathrm{~d},{ }^{1} \mathrm{~J}_{\mathrm{CF}}=249.4\right.$ $\mathrm{Hz}), 162.8\left(\mathrm{~d},{ }^{1} \mathrm{~J}_{\mathrm{CF}}=248.6 \mathrm{~Hz}\right), 129.9\left(\mathrm{~d},{ }^{4} \mathrm{~J}_{\mathrm{CF}}=3.7 \mathrm{~Hz}\right), 129.8\left(\mathrm{~d},{ }^{4} \mathrm{~J}_{\mathrm{CF}}=3.8 \mathrm{~Hz}\right), 129.2\left(\mathrm{~d},{ }^{2} \mathrm{~J}_{\mathrm{CF}}=\right.$ $8.8 \mathrm{~Hz}), 129.0\left(\mathrm{~d},{ }^{2} \mathrm{~J}_{\mathrm{CF}}=8.4 \mathrm{~Hz}\right), 116.7\left(\mathrm{~d},{ }^{3} \mathrm{~J}_{\mathrm{CF}}=22.0 \mathrm{~Hz}\right), 116.5\left(\mathrm{~d},{ }^{3} \mathrm{~J}_{\mathrm{CF}}=22.4 \mathrm{~Hz}\right), 88.3,87.4$, 75.6, 73.3, 16.4, $12.2 \mathrm{ppm}$; IR (NaCl) 3476, 1550, 1509, $1226 \mathrm{~cm}^{-1}$; MS (EI) m/z 152 (6), 124 (91), 123 (100), 95 (79), 75 (25). Anal. Calcd. For $\mathrm{C}_{9} \mathrm{H}_{10} \mathrm{FNO}_{3}$ : C, 54.27; H, 5.06; N, 7.03. Found: C, 53.89; H, 4.98; N, 6.96\%.

( \pm )-anti- and syn-2-Hydroxy-3-nitrobutyric acid ethyl ester (4f). By the general procedure, $150 \mathrm{mg}(85 \%)$ was obtained as a pale yellow oil from ethyl glyoxalate 1d, nitroethane 2a, and resin-supported amine $3 \mathbf{c}(0.2$ equiv. $)$ at $\mathrm{RT}$ during $1.5 \mathrm{~h}$. Data for $\mathbf{4 f}$ : ${ }^{1} \mathrm{H}-\mathrm{NMR}\left(\mathrm{CDCl}_{3}\right) \delta 4.91-$ $4.88(\mathrm{~m}, 1 \mathrm{H}), 4.81-4.78(\mathrm{~m}, 2 \mathrm{H}), 4.34-4.23(\mathrm{~m}, 5 \mathrm{H}), 3.40(\mathrm{brs}, 1 \mathrm{H}), 3.40(\mathrm{brs}, 1 \mathrm{H}), 1.64\left(\mathrm{~d},{ }^{3} \mathrm{~J}_{\mathrm{HH}}\right.$ $=6.9 \mathrm{~Hz}, 3 \mathrm{H}), 1.50\left(\mathrm{~d},{ }^{3} \mathrm{~J}_{\mathrm{HH}}=6.9 \mathrm{~Hz}, 3 \mathrm{H}\right), 1.28\left(\mathrm{t},{ }^{3} \mathrm{~J}_{\mathrm{HH}}=7.1 \mathrm{~Hz}, 6 \mathrm{H}\right) \mathrm{ppm} ;{ }^{13} \mathrm{C}-\mathrm{NMR}\left(\mathrm{CDCl}_{3}\right) \delta$ 171.0, 170.7, 83.3, 83.0, 71.8, 71.4, 62.9, 62.8, 14.9, 13.9, 13.9, 12.3 ppm; IR (NaCl) 3489, 
2992, 1746, 1554, 1394, 1368, $1268 \mathrm{~cm}^{-1}$; MS (EI) m/z $130\left(\mathrm{M}^{+}-\mathrm{HNO}_{2}, 7\right), 104$ (17), 85 (78), 76 (39), 57 (100). Anal. Calcd. for $\mathrm{C}_{6} \mathrm{H}_{11} \mathrm{NO}_{5}$ : C, 40.68; H, 6.26; N, 7.91. Found: C, 40.51; H, $6.17 ; \mathrm{N}, 7.87 \%$.

( \pm )-2-Hydroxy-3-nitropropionic acid ethyl ester (4g). ${ }^{22}$ As in the general procedure, $112 \mathrm{mg}$ $(69 \%)$ was obtained as a white solid from ethyl glyoxalate $\mathbf{1 d}$, nitromethane $\mathbf{2 b}$ and resinsupported amine 3a (0.2 equiv.) at RT for $6 \mathrm{~h}$. Data for $\mathbf{4 g}$ : $\mathrm{mp} 47-48{ }^{\circ} \mathrm{C} ;{ }^{1} \mathrm{H}-\mathrm{NMR}\left(\mathrm{CDCl}_{3}\right) \delta$ $4.71\left(\mathrm{dd},{ }^{3} \mathrm{~J}_{\mathrm{HH}}=4.4 \mathrm{~Hz},{ }^{2} \mathrm{~J}_{\mathrm{HH}}=1.8 \mathrm{~Hz}, 2 \mathrm{H}\right), 4.61\left(\mathrm{~d},{ }^{3} \mathrm{~J}_{\mathrm{HH}}=4.4 \mathrm{~Hz}, 1 \mathrm{H}\right), 4.29-4.20(\mathrm{~m}, 2 \mathrm{H}), 3.79$ $\left(\mathrm{d},{ }^{3} \mathrm{~J}_{\mathrm{HH}}=4.4 \mathrm{~Hz}, 1 \mathrm{H}\right), 1.24\left(\mathrm{t},{ }^{3} \mathrm{~J}_{\mathrm{HH}}=7.0 \mathrm{~Hz}, 3 \mathrm{H}\right) \mathrm{ppm} ;{ }^{13} \mathrm{C}-\mathrm{NMR}\left(\mathrm{CDCl}_{3}\right) \delta 170.7,76.8,67.5$, 62.8, 13.8 ppm; IR (KBr) 3397, 2992, 2939, 1739, 1560, $1388 \mathrm{~cm}^{-1}$. Anal. Calcd. for $\mathrm{C}_{5} \mathrm{H}_{9} \mathrm{NO}_{5}$ : C, 36.81; H, 5.56; N, 8.59. Found: C, 37.12; H, 5.48; N, 8.47\%.

anti- and syn-3-Amino-2-hydroxybutyric acid ethyl ester (5). Compound 4f (88.5 mg, $0.50 \mathrm{mmol})$ was dissolved in $\mathrm{EtOH}(7 \mathrm{ml})$ and Raney nickel $(200 \mathrm{mg})$ was added. The reaction was treated with $\mathrm{H}_{2}$ at $1 \mathrm{~atm}$. and left for $48 \mathrm{~h}$. The catalyst was filtered off and the crude product purified by flash-chromatography (silica gel, AcOEt-hexanes, 2:1) to yield the title compound 5, $50 \mathrm{mg}(68 \%)$ yield as a pale yellow oil. ${ }^{1} \mathrm{H}-\mathrm{NMR}\left(\mathrm{CDCl}_{3}\right) \delta 4.22-4.15(\mathrm{~m}, 4 \mathrm{H}), 4.09\left(\mathrm{~d},{ }^{3} \mathrm{~J}_{\mathrm{HH}}=\right.$ $3.5 \mathrm{~Hz}, 1 \mathrm{H}), 3.91\left(\mathrm{~d},{ }^{3} \mathrm{~J}_{\mathrm{HH}}=3.5 \mathrm{~Hz}, 1 \mathrm{H}\right), 3.26-3.17(\mathrm{~m}, 2 \mathrm{H}), 2.77$ (brs, 6H), $1.25\left(\mathrm{t},{ }^{3} \mathrm{~J}_{\mathrm{HH}}=7.0\right.$ $\mathrm{Hz}, 6 \mathrm{H}), 1.14\left(\mathrm{~d},{ }^{3} \mathrm{~J}_{\mathrm{HH}}=6.8 \mathrm{~Hz}, 3 \mathrm{H}\right), 1.00\left(\mathrm{~d},{ }^{3} \mathrm{~J}_{\mathrm{HH}}=6.5 \mathrm{~Hz}, 3 \mathrm{H}\right) \mathrm{ppm} ;{ }^{13} \mathrm{C}-\mathrm{NMR}\left(\mathrm{CDCl}_{3}\right) \delta$ 173.8, 173.0, 74.8, 74.3, 61.5, 61.4, 49.5,49.3, 20.1, 17.1, 14.1 ppm; IR (NaCl) 3443, 2991, 1743, $1553 \mathrm{~cm}^{-1}$; MS (CI) m/z $148\left(\mathrm{M}^{+}+1,100\right)$. Anal. Calcd. for $\mathrm{C}_{6} \mathrm{H}_{13} \mathrm{NO}_{3}: \mathrm{C}, 48.97 ; \mathrm{H}, 8.90$; N, 9.52. Found: C, 48.88; H, 8.93; N, 9.47\%.

\section{Acknowledgements}

The authors thank the Dirección General de Investigación del Ministerio de Ciencia y Tecnología (MCYT, Madrid DGI, BQU2000-0217) and the Universidad del País Vasco (UPV, GS/02) for supporting this work. J. M. de los Santos thanks the Ministerio de Ciencia y Tecnología (Madrid) for financial support through the Ramón y Cajal Program.

\section{References and Footnotes}

1. (a) Thompson, L. A.; Ellman, J. A. Chem. Rev. 1996, 96, 555. (b) Bhattacharyya, S. Comb. Chem. High Throughput Screening 2000, 3, 65.

2. For recent reviews see: (a) Nicolaou, K. C.; Pfefferkorn, J. A. Biopolymers 2001, 60, 171. (b) Kauhaluoma, Y. Tetrahedron 2001, 57, 7053. (c) Nefti, A.; Ostresh, J. M.; Houghten, R. A. In Solid-Phase Synthesis; Kates, S. A.; Albericio, F. Eds.; M. Dekker: New York, 2000; p 617. (d) Guillier, F.; Orain, D.; Bradley, M. Chem. Rev. 2000, 100, 2091. (e) Franzen, F. R. G. J. Comb. Chem. 2000, 2, 195.

3. For recent contributions see: (a) Cheng, W. C.; Wong, M.; Olmstead, M. M.; Kurth, M. J. 
Org. Lett. 2002, 4, 741. (b) Nefti, A.; Ostresh, J. M.; Houghten, R. A. Biopolymers 2001, 60, 212. (c) Caba, J. M.; Rodríguez, I. M.; Manzanares, I.; Giralt, E.; Albericio, F. J. Org. Chem. 2001, 66, 7568.

4. Palacios, F.; Aparicio, D.; de los Santos, J. M.; Baceiredo, A.; Bertrand, G. Tetrahedron 2000, 56, 663.

5. (a) Palacios, F. Aparicio, D.; Ochoa de Retana, A. M.; de los Santos, J. M.; Gil, J. I.; Alonso, J. M. J. Org. Chem. 2002, 67, 7283. (b) Palacios, F. Aparicio, D.; Ochoa de Retana, A. M.; de los Santos, J. M.; Gil, J. I.; López de Munain, R. Tetrahedron: Asymmetry 2003, 14,689 .

6. (a) Henry, L. C. R. Acad. Sci. Ser. C. 1895, 1265. (b) Henry, L. Bull. Soc. Chim. Fr. 1895, $13,999$.

7. For recent reviews see: (a) Luzzio, F. A. Tetrahedron 2001, 57, 915. (b) Rosini, G. In Comprehensive Organic Chemistry; Trost, B. M., Fleming, I.; Heathcock, C. H.; Eds; Pergamon Press: Oxford, 1991; Vol. 2, Ch. 1.10, p 32.

8. (a) Looper, R. E.; Williams, R. M. Angew. Chem., Int. Ed. 2004, 43, 2930. (b) Kudyba, I.; Raczko, J.; Jurczak, J. J. Org. Chem. 2004, 69, 2844. (c) Kudyba, I.; Raczko, J.; Jurczak, J. Tetrahedron Lett. 2003, 44, 8685. (d) Trost, B. M.; Yeh, V. S. C.; Ito, H.; Bremeyer, N. Org. Lett. 2002, 4, 2621. (e) Takaoka, E.; Yoshikawa, N.; Yamada, Y. M. A.; Sasai, H.; Shibasaki, M. Heterocycles 1997, 46, 157. (f) Sasai, H.; Itoh, N.; Suzuki, T.; Shibasaki, M. Tetrahedron Lett. 1993, 34, 855. (g) Williams, T. M.; Mosher, H. S. Tetrahedron Lett. 1985, 26, 6269. (h) Suami, T.; Tadono, K. I.; Suga, A.; Ueno, Y. J. Carbohydr. Chem. 1984, 3, 429.

9. Ono, N. In The Nitro Group in Organic Synthesis; Feuer, H., Ed.; Wiley-VCH: New York, 2001 .

10. (a) Simoni, D.; Rondanin, R.; Morini, M.; Baruchello, R.; Invidiata, F. P. Tetrahedron Lett. 2000, 41, 1607. (b) Caldarelli, M.; Habermann, J.; Ley, S. V. J. Chem. Soc., Perkin Trans. 1 1999, 107.

11. (a) For a review see: Shibasaki, M.; Sasai, H.; Arai, T. Angew. Chem., Int. Ed. 1997, 36, 1236. (b) Sasai, H.; Tokunaga, T.; Watanabe, S.; Suzuki, T.; Itoh, N.; Shibasaki, M. J. Org. Chem. 1995, 60, 7388. (c) Sasai, H.; Suzuki, T.; Arai, S.; Arai, T.; Shibasaki, M. J. Am. Chem. Soc. 1992, 114, 4418.

12. (a) Trost, B. M.; Yeh, V. S. C. Angew. Chem., Int. Ed. 2002, 41, 861. (b) Chistensen, C.; Juhl, K.; Hazell, R. G.; Jørgensen, K. A. J. Org. Chem. 2002, 67, 4875. (c) Knudsen, K. R.; Risgaard, T.; Nishiwaki, N.; Gothelf, K. V.; Jørgensen, K. A. J. Am. Chem. Soc. 2001, 123, 5843.

13. For the complete characterization of this compound see: Ballini, R.; Bosica, G. J. Org. Chem. 1997, 62, 425.

14. Chiral polymer-supported amine 3c was characterized by FTIR and elemental analyses see Experimental Section.

15. Takaoka, E.; Yoshikawa, N.; Yamada, Y. M. A.; Sasai, H.; Shibasaki, M. Heterocycles 
1997, 46, 157.

16. Knudsen, K. R.; Risgaard, T.; Nishiwaki, N.; Gothelf, K. V.; Jørgensen, K. A. J. Am. Chem. Soc. 2001, 123, 5843.

17. (a) Lubisch, W.; Beckenbach, E.; Bopp, S.; Hofmann, H. -P.; Kartal, A.; Kaestel, C.; Lindner, T.; Metz-Garrecht, M.; Reeb, J.; Regner, F.; Vierling, M.; Moeller, A. J. Med. Chem. 2003, 46, 2404. (b) Solladie-Cavallo, A.; Khiar, N. J. Org. Chem. 1990, 55, 4750.

18. For reviews, see: (a) Juaristi, E. In Enantioselective Synthesis of $\beta$-Amino Acids; WileyVCH: New York, 1997. (b) Cardillo, G.; Tomasini, C. Chem. Soc. Rev. 1996, 29, 117.

19. (a) Nicolau, K. C.; Dai, W. -M.; Guy, R. K. Angew. Chem., Int. Ed. 1994, 33, 15. (b) Miura, K.; Sawa, T.; Takeuchi, H.; Umezawa, H. J. Antibiotic 1986, 39, 734. (c) Iizaka, K.; Kamijo, T.; Harada, H.; Akahane, K.; Kubota, T.; Umeyama, H.; Ishida, T.; Kiso, Y. J. Med. Chem. 1990, 33, 2707. (d) Umezawa, H.; Aoyagi, T.; Suda, H.; Hamada, M.; Takeuchi, T. J. Antibiotic 1976, 29, 97. (e) Okino, T.; Matsuda, H.; Murakami, M.; Yamaguchi, K. Tetrahedron Lett. 1993, 34, 501.

20. For the complete characterization of this compound see: Evans, D. A.; Seidel, D,; Rueping, M.; Wai Lam, H.; Shaw, J. T.; Downey, C. W. J. Am. Chem. Soc. 2003, 125, 12692.

21. For the complete characterization of this compound see: Ballini, R.; Bigi, F.; Gogni, E.; Maggi, R.; Sartori, G. J. Catal. 2000, 191, 348.

22. For the complete characterization of this compound see: Yasohara, Y.; Hasegawa, J. Biosci. Biotechnol. Biochem. 2001, 65, 1258. 